\title{
Plasmid content and localisation of the STal (STaP) gene in enterotoxigenic Escherichia coli with a non-radioactive polynucleotide gene probe
}

\section{A. BERTIN}

Laboratoire de Pathologie Infectieuse et Immunologie, Institut National de la Recherche Agronomique, Centre de Recherches de Tours, 37380 Nouzilly, France

\begin{abstract}
Summary. Enterotoxigenic Escherichia coli (ETEC) strain P2200 of porcine origin possessed eight possibly plasmid-determined characters $\left(\mathrm{K} 88^{+} \mathrm{Raf}^{+} \mathrm{Hly}^{+} \mathrm{Col}^{+} \mathrm{Sm}^{\mathrm{r}} \mathrm{Tc}^{\mathrm{r}} \mathrm{Su}^{\mathrm{r}} \mathrm{STa}{ }^{+}\right)$and six plasmid DNA bands of $4 \cdot 2-93 \mathrm{~kb}$. Analysis of the spontaneous loss of characters and the results of matings with other $E$. coli strains revealed that the $\mathrm{K} 88$, Raf, $\mathrm{Hly}, \mathrm{Sm}^{\mathrm{r}}$, $\mathrm{Tc}^{\mathrm{r}}$ and $\mathrm{Su}^{\mathrm{r}}$ characters could be transferred, and that the presence of the K88 and Raf characters was associated with an $83-\mathrm{kb}$ plasmid. The presence and location of the STaI gene was investigated in several ETEC strains of bovine or porcine origin. Hybridisation with a non-radioactive polynucleotide probe associated the STaI gene with a plasmid in each strain; these plasmids were of 32-142 kb. In contrast, plasmids from a P2200 STa ${ }^{-}$variant and plasmids from two $\mathrm{STa}^{-}$variants of the bovine ETEC strain B41* (strain B41 obtained from a different source) did not hybridise with the probe. One of the $\mathrm{B} 4{ }^{*} \mathrm{STa}^{-}$variants had lost the STa plasmid, whereas the second variant retained a plasmid of the same size which did not hybridise. In contrast, a third $\mathrm{B} 41^{*} \mathrm{STa}^{-}$variant retained a plasmid of the same size that still hybridised with the STaI probe. Plasmid DNA restriction fragment analysis, followed by hybridisation with the STaI probe, showed that the STaI gene was associated with 8.3-, 6.8- and 3.5-kb plasmid fragments in strain B41, and with 4.9-, 6.8- and 3.5-kb plasmid fragments in strain B41*, following digestion with EcoRI, BamHI, or EcoRI + BamHI, respectively. The STaI probe hybridised also with $12 \cdot 2-\mathrm{kb} E c o \mathrm{RI}$ and $4 \cdot 6-\mathrm{kb}$ BamHI fragments of the plasmid from the third $\mathrm{B} 41^{*} \mathrm{STa}^{-}$variant, that unexpectedly had given an initial positive hybridisation result. Different plasmid restriction fragment profiles were seen for strains B41 and B41*, the $\mathrm{B} 4{ }^{*} \mathrm{STa}^{-}$variants and the transconjugant strains, thereby providing further evidence that molecular rearrangements of these plasmids can occur spontaneously.
\end{abstract}

\section{Introduction}

Several virulence factors have been identified in strains of enterotoxigenic Escherichia coli (ETEC). These include plasmid-encoded toxins that cause intestinal cells to lose water and electrolytes, and plasmid- or chromosome-encoded adhesins (CFA) that confer the ability to adhere to intestinal cells. Adhesins are often pili or pili-like structures that are antigenically identifiable. Different plasmid- or chromosome-encoded adhesins have been identified in ETEC strains of human origin. Similarly, adhesins K99 (in ETEC strains from calves, pigs and lambs) and K88 (in ETEC strains from pigs) are plasmidencoded, whereas F41 (in ETEC strains from calves, pigs and lambs) is chromosome-encoded. ${ }^{1-3}$ More recently, another adhesin named 987P (in ETEC strains from pigs), originally thought to be encoded by the chromosome, has also been found to be encoded by a plasmid. ${ }^{4}$ The identified toxins include heat-labile toxin (LT), which possesses similarities with cholera toxin, and several heat-stable toxins that are active either in the suckling mouse assay (STa) or only in the pig intestine (STb). ${ }^{5}$ Some structural and genetic heterogeneity has been found in STa toxins produced by bacteria of human and porcine origins. ${ }^{5}$

STa and LT toxins have been shown to be encoded by several different plasmids. Plasmids coding for STa + LT in human and pig strains of bacteria are usually considered to be highly related; plasmids coding for STa only, and probably those coding for LT only, are more heterogenous. ETEC strains usually contain several distinct plasmid types, and adhesins have sometimes, but not always, been reported to be encoded by the same plasmid as toxin or antibiotic resistances. Recombination or transposition events have also been described. ${ }^{6-8}$

In only a limited number of cases has toxin production been associated with a particular plasmid 
and with other characters, largely because it is difficult to separate the various plasmids in a particular strain without a readily selectable genetic marker. DNA probes for toxin genes are now available, and these enable information to be obtained readily about the location, stability, recombination events, dissemination and occurrence of such genes in strains that do not express toxin.

This work reports the results of a study in which the phenotypic characters of an ETEC strain of porcine origin were correlated with its plasmid content following spontaneous loss of characters, and transconjugants obtained in matings with other $E$. coli strains were analysed. In addition, a non-radioactive STaI polynucleotide gene probe (termed STaP in strains of porcine origin) was investigated for its suitability to determine the occurrence and location of the STaI gene on plasmids from the porcine strain studied, together with other ETEC strains or STa ${ }^{-}$variants of different origins.

\section{Materials and methods}

\section{Bacterial strains}

Strain P2200 was a $\mathrm{K}^{2} 8^{+}$ETEC strain of porcine origin. ${ }^{9,}{ }^{10}$ Strain $\mathrm{B} 41$ was a bovine $\mathrm{K}^{49}{ }^{+} \mathrm{STa}^{+}$reference ETEC strain, ${ }^{11}$ and strain B41* was supposedly identical, but was obtained from a different source, ${ }^{12}$ these two stains had a different plasmid content. ${ }^{12}$ Strain $\mathrm{B} 41^{*} \mathrm{C}$ was derived from strain B41*, but had lost a $90-\mathrm{MDa}(142-\mathrm{kb})$ plasmid, together with the ability to produce STa toxin and K99 adhesin. ${ }^{12}$ Recipient strains used in plasmid transfers were: C600PK 1046, (resistant to rifampicin, C600 rif $^{r}$ ); a nalidixic resistant mutant of another $E$. coli $\mathrm{K} 12(E$. coli $\mathrm{K} 12 \mathrm{nal}^{\mathrm{r}}$ ); $\mathrm{C} 13$, a non-enterotoxigenic strain of $E$. coli $;{ }^{9}$ and a nalidixic acid-resistant mutant of strain B4 $1^{*} \mathrm{C} .{ }^{12}$ The origins and characteristics of the porcine ETEC strains 431, 987 and 1676, and the bovine ETEC strains B44, B80 and B117 have been described previously. ${ }^{10,13-15}$ Each ETEC strain produced STa. Strain G157, provided by S. L. Moseley (University of Washington, School of Medicine, Seattle, Washington, USA), was used as a source of the STaI probe. Strain G157 carries plasmid pDAS101, comprising a 157-bp HinfI fragment from pRIT1036 which had been blunt-ended by an end-fill reaction and cloned into the SmaI site of pUC8.

\section{Characterisation of bacterial strains}

Antisera specific for $\mathrm{K} 99$ and $\mathrm{K} 88$ were produced as described previously. ${ }^{9,12}$ Tests for the ability to ferment carbohydrates were made either with the API50 system (API System S.A., La Balme les Grottes, Montalieu-Vercieu, France) or in peptone water with phenol red. Production of haemolysin was detected on Sheep-Blood Agar (Difco, Detroit, MI, USA). Pro- duction of colicins was detected by the agar-overlay method of Fredericq. ${ }^{16}$ Resistance to antibiotics was detected by placing antibiotic-containing disks (bioMérieux, Charbonnière Les Bains, France) on cultures spread on Mueller Hinton Agar (bioMérieux) plates. STa toxin production was determined by the suckling mouse assay. ${ }^{17} \mathrm{~A}$ strain giving a positive result in this test was designated $\mathrm{STa}^{+}$, and a strain giving a negative result was designated $\mathrm{STa}^{-}$.

\section{Plasmid transfers}

Donor and recipient strains were grown, without shaking, for $24 \mathrm{~h}$ at $37^{\circ} \mathrm{C}$ in $10 \mathrm{ml}$ of Trypticase Soy Broth (bioMérieux). Equal portions $(200 \mu \mathrm{l})$ of each culture were mixed and incubated for a further $18 \mathrm{~h}$ at $37^{\circ} \mathrm{C}$. Transconjugants were selected on Trypticase Soy Agar (bioMérieux) supplemented with appropriate antibiotics: streptomycin $2.5 \mathrm{mg} / \mathrm{L}$; sulphadiazine $100 \mathrm{mg} / \mathrm{L}$; rifampicin $32 \mathrm{mg} / \mathrm{L}$; nalidixic acid $40 \mathrm{mg} / \mathrm{L}$.

\section{Plasmid analysis}

After alkaline extraction, ${ }^{18}$ the plasmid content of each strain was analysed by electrophoresis on vertical agarose $0.8 \%$ gels in a Protean gel apparatus (BioRad Laboratories, Paris, France). The sample slots contained $40 \mu \mathrm{l}$ of a plasmid extract. Electrophoresis was normally at $100 \mathrm{~V}$ for $150 \mathrm{~min}$ in TAE buffer. ${ }^{19} \mathrm{Gels}$ were stained for $30 \mathrm{~min}$ with ethidium bromide $0.5 \mathrm{mg} / \mathrm{L}$ and photographed under UV light on to Polaroid type $665 \mathrm{film}$. The molecular sizes of plasmids were estimated from a linear regression curve constructed from the mobility of standard plasmids of known molecular size.

\section{Restriction fragment analysis}

Plasmid DNA was extracted by the method of Birnboim and Doly, ${ }^{20}$ and then digested with either EcoRI, BamHI (Appligène, Illkirch, France), or both, in $\mathrm{H}$ buffer ${ }^{19}$ for $150 \mathrm{~min}$ at $37^{\circ} \mathrm{C}$, followed by ethanol precipitation and resuspension in $15 \mu \mathrm{l}$ of TAE. Electrophoresis was performed in TAE on agarose $1 \%$ gels in a horizontal gel electrophoresis system (Model H4; Bethesda Research Laboratories, Gaithersburg, MD, USA). Samples and fragments of known size ( $\lambda$-BstEII; Appligène) were electrophoresed for $18 \mathrm{~h}$ at $30 \mathrm{~V}$, stained with ethidium bromide and photographed as described above.

\section{Probe extraction and purification}

Plasmid pDAS101 was extracted by the method of Holmes and Quigley, ${ }^{21}$ and was then digested with EcoRI and BamHI as described above. The 157-bp fragment was isolated from a polyacrylamide $8 \%$ gel as described previously, ${ }^{22}$ but with the modification of Bialkowska-Hobrzanska. ${ }^{23}$ Two cycles of purification 
Table I. Plasmid content and phenotypic characters associated with porcine ETEC strain P2200 and its spontaneous variants

\begin{tabular}{|c|c|c|c|c|c|c|c|c|c|c|c|c|c|c|}
\hline \multirow{2}{*}{$\begin{array}{l}\text { Bacterial } \\
\text { strains }\end{array}$} & \multicolumn{6}{|c|}{ Plasmid content $(\mathbf{k b})$} & \multicolumn{8}{|c|}{ Phenotype } \\
\hline & 93 & 83 & 55 & $6 \cdot 3$ & $5 \cdot 2$ & $4 \cdot 2$ & K88 & Raf & Hly & $\mathrm{Col}$ & $\mathrm{Sm}$ & Tc & $\mathrm{Su}$ & STa \\
\hline Original strain & & & & & & & & & & & & & & \\
\hline $\begin{array}{r}\text { P2200 } \\
\text { Varant }\end{array}$ & + & + & + & + & + & + & + & + & + & + & $\mathbf{R}$ & $\mathbf{R}$ & $\mathbf{R}$ & + \\
\hline $\begin{array}{l}\text { Variants } \\
\text { P2200 Raf }\end{array}$ & + & - & + & + & + & + & - & - & + & + & $\mathbf{R}$ & $\mathbf{R}$ & $\mathbf{R}$ & + \\
\hline $\mathrm{P} 2200 \mathrm{STa}^{-}$ & + & + & + & + & + & + & + & + & + & - & $\mathbf{R}$ & $\mathbf{R}$ & $\mathbf{R}$ & - \\
\hline
\end{tabular}

Table II. Plasmid content and phenotypic characters associated with transconjugants obtained in matings with ETEC strain P2200

\begin{tabular}{|c|c|c|c|c|c|c|c|c|c|c|c|c|c|c|}
\hline \multirow{2}{*}{$\begin{array}{l}\text { Recipient } \\
\text { strains and } \\
\text { transconjugants* }\end{array}$} & \multicolumn{6}{|c|}{ Plasmid content $(\mathbf{k b})$} & \multicolumn{8}{|c|}{ Phenotype } \\
\hline & 93 & 83 & 55 & $6 \cdot 3$ & $5 \cdot 2$ & $4 \cdot 2$ & K88 & Raf & Hly & Col & Sm & Tc & $\mathrm{Su}$ & STa \\
\hline C600 rif ${ }^{x}$ & - & - & - & - & - & - & - & - & - & - & $\mathrm{s}$ & $\mathrm{s}$ & $\mathbf{s}$ & - \\
\hline $\begin{array}{l}{\mathrm{C} 600 \mathrm{Raf}^{+}}^{+} \\
(\mathrm{A}, \mathrm{D}, \mathrm{F}, \mathrm{I}, \mathrm{J})\end{array}$ & + & + & - & + & + & + & + & + & - & - & $\mathbf{R}$ & $\mathbf{S}$ & $\mathbf{R}$ & - \\
\hline $\begin{array}{l}\mathrm{C} 600 \mathrm{Raf}^{+} \\
(\mathrm{B}, \mathrm{C})\end{array}$ & - & + & - & + & - & - & + & + & - & - & $\mathbf{R}$ & $\mathbf{S}$ & $\mathbf{R}$ & - \\
\hline $\begin{array}{c}\mathrm{C}^{2} 600 \mathrm{Raf}^{+} \\
(\mathrm{E}, \mathrm{G}, \mathrm{H})\end{array}$ & - & + & - & + & + & + & + & + & - & - & $\mathbf{R}$ & $\mathbf{S}$ & $\mathbf{R}$ & - \\
\hline $\mathrm{B} 41^{*} \mathrm{C}$ nal ${ }^{\mathrm{r}}$ & - & - & - & - & - & - & - & - & - & - & $\mathbf{S}$ & $\mathbf{S}$ & $\mathbf{S}$ & - \\
\hline $\begin{array}{c}\mathrm{B} 41^{*} \mathrm{C} \mathrm{Raf}^{+} \\
(1,3,4,5)\end{array}$ & + & + & - & - & - & - & + & + & - & - & S & $\mathbf{S}$ & $\mathbf{S}$ & - \\
\hline $\begin{array}{l}\mathrm{B} 41^{*} \mathrm{C} \mathrm{Raf}^{+} \\
(2,6)\end{array}$ & - & + & - & - & - & - & + & + & - & - & $\mathbf{S}$ & $\mathrm{S}$ & $\mathbf{S}$ & - \\
\hline E. coli $\mathrm{K} 12 \mathrm{nal}^{\mathrm{r}}$ & \multirow{2}{*}{\multicolumn{6}{|c|}{$\begin{array}{l}\text { NT } \\
\text { NT }\end{array}$}} & - & - & - & - & $\mathbf{S}$ & $\mathbf{S}$ & $\mathrm{S}$ & - \\
\hline $\begin{array}{l}\text { E. coli K12 } \mathrm{Raf}^{+} \\
\text {(A) }\end{array}$ & & & & & & & + & + & - & - & $\mathbf{R}$ & $\mathrm{S}$ & $\mathbf{R}$ & - \\
\hline $\begin{array}{l}\text { E. coli } \mathrm{K} 12 \mathrm{Raf}^{+} \\
\text {(B) }\end{array}$ & \multicolumn{6}{|c|}{ NT } & + & + & + & - & $\mathbf{R}$ & $\mathbf{S}$ & $\mathrm{S}$ & - \\
\hline $\begin{array}{l}\text { E. coli } \mathrm{K} 12 \mathrm{Raf}^{+} \\
\text {(C) }\end{array}$ & \multicolumn{6}{|c|}{ NT } & + & + & - & - & $\mathbf{R}$ & $\mathbf{R}$ & $\mathbf{R}$ & - \\
\hline
\end{tabular}

NT, not tested.

*Transconjugant designations are shown in parentheses.

were carried out and the homogeneity of the purified DNA fragment was verified on a polyacrylamide $5 \%$ gel.

\section{Southern transfers}

Gels were first treated successively with: $0.25 \mathrm{M} \mathrm{HCl}$ for $15 \mathrm{~min} ; 0.5 \mathrm{M} \mathrm{NaOH}, 1.5 \mathrm{M} \mathrm{NaCl}$ for two 30 -min periods; and $0.5 \mathrm{M}$ Tris- $\mathrm{HCl}, \mathrm{pH} 7.0,3.0 \mathrm{M} \mathrm{NaCl}$ for two 20-min periods. QNA was then transferred to Nylon Hybond-N membranes (Amersham France, Les Ulis, France) in $10 \times \mathrm{SSC}$ (SSC was $150 \mathrm{~mm} \mathrm{NaCl}$, $15 \mathrm{~mm}$ sodium citrate, $\mathrm{pH} 7.0$ ), and was fixed by baking at $80^{\circ} \mathrm{C}$ for $2 \mathrm{~h}$.

\section{STaI gene detection}

Purified STaI probe DNA was labelled by random priming with digoxigenin (Non-Radioactive DNA Labelling and Detection Kit; Boehringer-Mannheim, Meylan, France), and hybridised with plasmid DNA transferred previously to Hybond-N membranes as described above. Pre-hybridisation ( $3 \mathrm{~h}$ ) and hybridisation (overnight) were performed in the absence of formamide at $68^{\circ} \mathrm{C}$. The probe concentration in the hybridisation medium was 50 or $100 \mathrm{ng} / \mathrm{ml}$.

\section{Results}

Derivatives of strain P2200 were selected by spontaneous loss of phenotypic characters (STa, Raf). These were analysed for their plasmid content and were compared with transconjugants obtained in matings with other strains of $E$. coli (tables I and II). Six plasmid DNA bands were identified in strain P2200. Although the association of characters with the presence of a particular plasmid DNA band was not easy, the K88 and Raf characters could be associated with the presence of the $83-\mathrm{kb}$ plasmid. The $55-\mathrm{kb}$ plasmid was neither transferred nor eliminated, and the 93-, 5-2- and 4.2-kb plasmids did not appear to be associated with the characters studied. It was not possible to link the STa character to the presence of a 
A

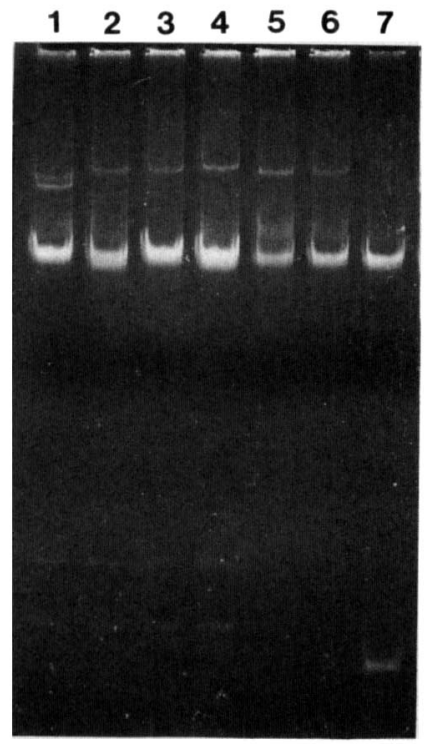

B

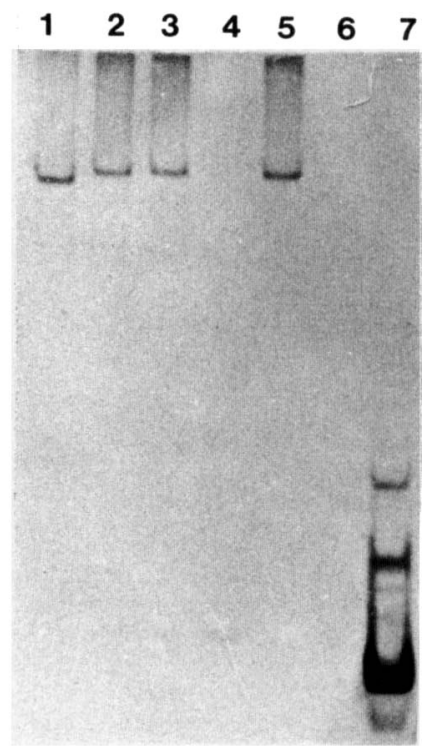

Fig. 1. Plasmid content (A) and Southern blot following hybridisation with the STaI probe (B) of selected strains and transconjugants. Lane 1 , strain $\mathrm{B} 41 ; 2$, strain $\mathrm{B} 41^{*} ; 3$, strain $\mathrm{B} 41^{*} \mathrm{Tc}^{\mathrm{s}} 1 ; 4$, strain $\mathrm{B} 41^{*} \mathrm{Tc}^{\mathrm{s}} 2 ; 5$, transconjugant $\mathrm{C} 600 \mathrm{Tc}^{8} 1 ; 6$, transconjugant $\mathrm{C} 600 \mathrm{Tc}^{\mathrm{s}} 2 ; 7$, strain $\mathrm{G} 157$ (pDAS101).

A

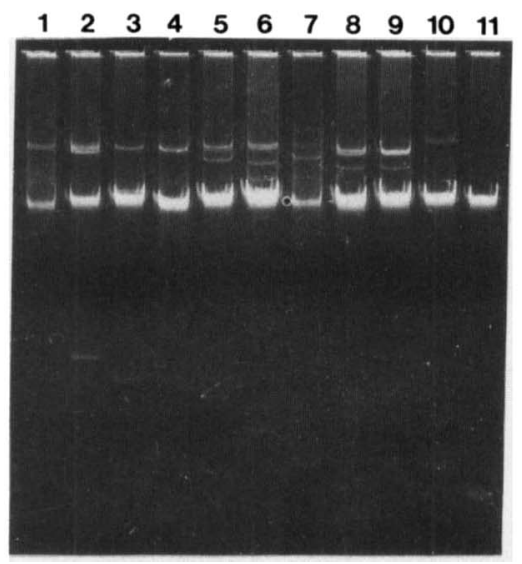

B

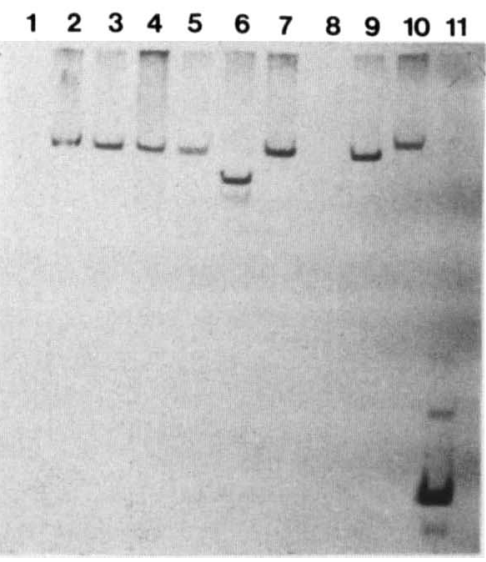

Fig. 2. Plasmid content (A) and Southern blot following hybridisation with the STaI probe (B) of selected strains of $E$. coli. Lane 1, strain C13; 2, strain B44; 3, strain B80; 4, strain B117; 5, strain 431; 6, strain 987; 7, strain 1676; 8, STaI ${ }^{-}$variant of strain P2200; 9, strain P2200; 10, strain $\mathrm{B} 41^{*} ; 11$, strain G157 (pDAS101).

particular plasmid DNA band. A further observation was that $\mathrm{C} 600 \mathrm{Raf}^{+}$transconjugants also acquired the ability to ferment melibiose.

The location of the STaI gene in several ETEC strains of bovine or porcine origin was investigated. Strain B41 possessed four plasmid DNA bands. ${ }^{12}$ The $105-\mathrm{kb}(67-\mathrm{MDa})$ plasmid was associated with the presence of $\mathrm{K} 99$ antigen and production of STa toxin, whereas the $87-\mathrm{kb}(55-\mathrm{MDa})$ plasmid was associated with resistance to streptomycin, tetracycline and sulphonamides. In contrast, all these phenotypic characters were encoded by a $142-\mathrm{kb}(90-\mathrm{MDa})$ plasmid in strain $\mathrm{B} 41^{*}{ }^{12}$ Of three $\mathrm{STa}^{-}$derivatives of strain $\mathrm{B} 41^{*}$ selected by loss of tetracycline resistance, one had lost the 142-kb plasmid and its associated characters (strain $\left.\mathrm{B} 41^{*} \mathrm{C}\right)$; the other two derivatives, $\mathrm{B} 41^{*} \mathrm{Tc}^{\mathrm{s}} 1$ and
$\mathrm{B} 41^{*} \mathrm{Tc}^{\mathrm{s}} 2$, retained resistance to streptomycin and sulphonamides. ${ }^{12}$ These resistances were transferred by conjugation to $E$. coli $\mathrm{C} 600$ to produce transconjugants designated $\mathrm{C} 600 \mathrm{Tc}^{\mathrm{s}} 1$ and $\mathrm{C} 600 \mathrm{Tc}^{\mathrm{s}} 2$, respectively. Strains $\mathrm{B} 41^{*} \mathrm{Tc}^{\mathrm{s}} 1$ and $\mathrm{B} 41^{*} \mathrm{Tc}^{\mathrm{s}} 2$ retained a plasmid DNA band migrating at about the same level as that of strain B41* (fig. 1A). Results obtained with the STaI probe showed that the 142-kb plasmid from strain $\mathrm{B} 41^{*} \mathrm{Tc}^{\mathrm{s}} 1$ retained the ability to hybridise with the probe, whereas the plasmid from strain $\mathrm{B} 41^{*} \mathrm{Tc}^{\mathrm{s}} 2$ did not hybridise (fig. 1B). Corresponding results were obtained with transconjugants $\mathrm{C} 600 \mathrm{Tc}^{\mathrm{s}} 1$ and C600Tc 2 (fig. 1B).

Further hybridisation experiments showed that each enterotoxigenic strain in the study carried a plasmid that hybridised with the STaI probe (figs. 2A and B). 
Table III. Plasmid content and hybridisation properties of the $E$. coli strains studied

\begin{tabular}{|c|c|c|}
\hline $\begin{array}{l}\text { Bacterial } \\
\text { strain }\end{array}$ & $\begin{array}{l}\text { Approximate plasmid } \\
\text { sizes }(\mathrm{kb})\end{array}$ & $\begin{array}{l}\text { Plasmid } \\
\text { hybridising with } \\
\text { STaI probe }(\mathrm{kb})\end{array}$ \\
\hline $\begin{array}{l}\mathrm{B} 41 \\
\mathrm{~B} 41^{*} \\
\mathrm{~B} 41^{*} \mathrm{Tc}^{\mathrm{s}} 1 \\
\mathrm{~B} 41^{*} \mathrm{Tc}^{\mathrm{s}} 2 \\
\mathrm{C} 600 \mathrm{Tc}^{\mathrm{s}} 1 \\
\mathrm{C} 600 \mathrm{Tc}^{\mathrm{s}} 2 \\
\mathrm{~B} 44 \\
\mathrm{~B} 80 \\
\mathrm{~B} 117 \\
431 \\
987 \\
1676 \\
\mathrm{P} 2200 \\
\mathrm{P} 2200 \mathrm{STa}^{-} \\
\mathrm{C} 13\end{array}$ & $\begin{array}{l}105,87,4 \cdot 9,3 \cdot 6 \\
142,4 \cdot 9,3 \cdot 6 \\
142,4 \cdot 9,3 \cdot 6 \\
142,4 \cdot 9,3 \cdot 6 \\
142 \\
142 \\
107,88,10 \cdot 1 \\
107,7 \cdot 9,3 \cdot 3 \\
95 \\
110-105,61,6 \cdot 5,3 \cdot 5 \\
118,104,57,32,5 \cdot 8,4 \cdot 7 \\
102,71,11 \cdot 2,3 \cdot 5 \\
93,83,55,6 \cdot 3,5 \cdot 2,4 \cdot 2 \\
93,83,55,6 \cdot 3,5 \cdot 2,4 \cdot 2 \\
107\end{array}$ & $\begin{array}{c}105 \\
142 \\
142 \\
\text { None } \\
142 \\
\text { None } \\
107 \\
107 \\
95 \\
110-105 \\
32 \\
102 \\
93 \\
\text { None } \\
\text { None }\end{array}$ \\
\hline
\end{tabular}

The plasmids carried by the non-enterotoxigenic strain $\mathrm{C} 13$ and an $\mathrm{STa}^{-}$derivative of strain P2200 did not hybridise with the STaI probe (figs. $2 \mathrm{~A}$ and B). Table III summarises the results obtained from several agarose gels regarding the plasmid content and hybridisation properties of the strains studied.

To investigate the genetic modifications which might be occurring, plasmid restriction profiles were compared for strains B41*, B41* $\mathrm{Tc}^{\mathrm{s}} 1, \mathrm{~B} 41^{*} \mathrm{Tc}^{\mathrm{s}} 2, \mathrm{C} 600 \mathrm{Tc}^{\mathrm{s}} 1$ and $\mathrm{C} 600 \mathrm{Tc}^{\mathrm{s}} 2$. The small plasmids $(3.6$ and $4.9 \mathrm{~kb})$ were not cut by the restriction enzymes used in these experiments. The complex data obtained following restriction endonuclease treatment of the other plasmids (results not shown) demonstrated differences between the original strains B41 and B41*, as well as
Table IV. Summary of hybridisation results obtained with the STaI probe and plasmid restriction fragments from selected strains

\begin{tabular}{l|ccc}
\hline \multirow{2}{*}{ Strain } & \multicolumn{3}{|c}{ DNA fragments (kb) hybridising with } \\
the STaI probe
\end{tabular}

between the $\mathrm{STa}^{-}$derivatives and transconjugants obtained following transfer to $E$. coli $\mathrm{C} 600$.

Hybridisation results obtained with the STaI probe confirmed that the plasmid from strain $\mathrm{B} 41^{*} \mathrm{Tc}^{\mathrm{s}} 2$ had lost the STaI gene, because no hybridisation occurred with any fragment (figs. 3A, B, C). In contrast, hybridisation occurred with a $12 \cdot 2-\mathrm{kb}$ EcoRI fragment and a 4.6-kb BamHI fragment from strain $\mathrm{B} 41^{*} \mathrm{Tc}^{\mathrm{s}} 1$. The STaI gene was located to different EcoRI fragments, 8.3 and $4.9 \mathrm{~kb}$ respectively, from strains B41 and $\mathrm{B} 41^{*}$, but was found on the same $6 \cdot 8-\mathrm{kb}$ Bam HI and $3 \cdot 5-\mathrm{kb} E c o \mathrm{RI}+B a m \mathrm{HI}$ fragments from these strains. The results are summarised in table IV.

\section{Discussion}

Each ETEC strain studied was found to contain between one and six plasmids, and in each strain it was possible to use the non-radioactive polynucleotide probe to localise the STaI gene to one of the plasmids,
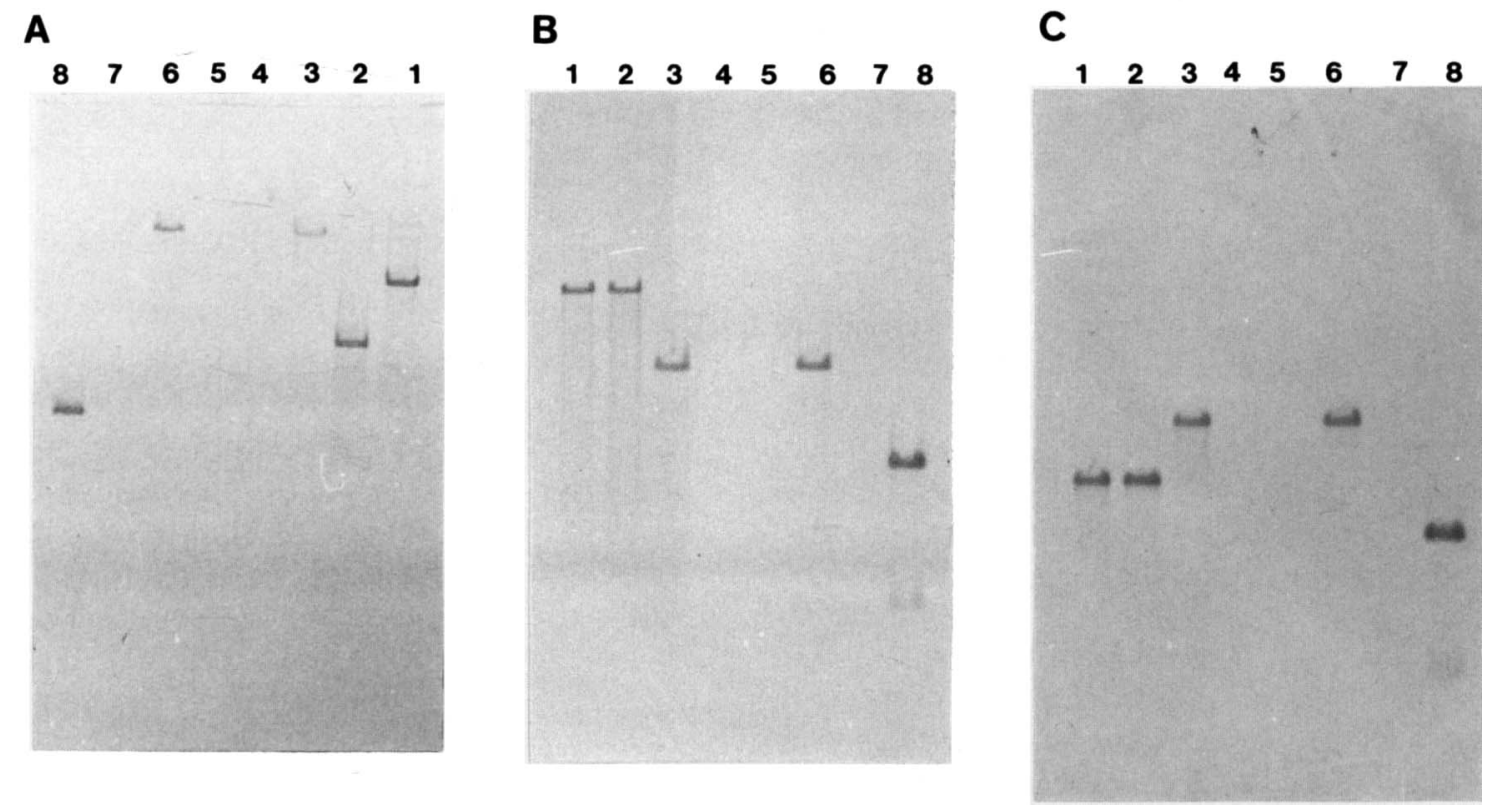

Fig. 3. Southern blots of plasmid DNA from selected strain and transconjugants, digested with restriction endonucleases and hybridised with the STaI probe. Digest: (A) EcoRI; (B) BamHI; (C) EcoRI + BamHI. Lane 1, strain B41; 2, strain B41*; 3, strain B41*Tc 1 ; 4, strain $\mathrm{B}^{*}{ }^{*} \mathrm{Tc}^{\mathrm{s}} 2 ; 5$, strain $\mathrm{B} 41^{*} \mathrm{C} ; 6$, transconjugant $\mathrm{C} 600 \mathrm{Tc}^{\mathrm{s}} 1 ; 7$, transconjugant $\mathrm{C} 600 \mathrm{Tc}^{\mathrm{s}} 2 ; 8$, strain G157 (pDAS101) linearised by EcoRI. 
ranging in size from 32 to $142 \mathrm{~kb}$. Strain P2200 contained six plasmids, of which a 93-kb plasmid hybridised with the STaI probe. Although one of the $\mathrm{STa}^{-}$derivatives isolated from strain P2200 apparently retained this plasmid, no hybridisation was detected. One possibility is that strain P2200 might contain more than one plasmid that migrated at this level, and there was evidence for this possibility on some of the gels examined (results not shown). With some other strains, a few anomalies were also observed when compared with previous studies which examined the location of the STaI gene with radioactivelylabelled probes. ${ }^{4,24}$ However, it has been reported ${ }^{25}$ that the STa gene is located on a transposon, and this could account for any apparent changes in its precise location.

The location of the STaI gene was investigated in detail for strains B41, B41*, B41* $\mathrm{Tc}^{\mathrm{s}} 1$ and $\mathrm{B} 41^{*} \mathrm{Tc}^{\mathrm{s}} 2$, as well as in the transconjugants $C 600 \mathrm{Tc}^{\mathrm{s}} 1$ and $\mathrm{C} 600 \mathrm{Tc}^{\mathrm{s}} 2$, following restriction endonuclease digestion of plasmid DNA. Since it was first isolated, several reports have described different plasmid contents and associated characters for strain B41. ${ }^{26,27}$ In the present study, the STaI gene was localised to different plasmid $E c o$ RI fragments in strains B41 and $B 41^{*}$ (8.3 and $4.9 \mathrm{~kb}$, respectively), but to the same BamHI $(6 \cdot 8-\mathrm{kb})$ and EcoRI + BamHI $(3 \cdot 5-\mathrm{kb})$ fragments. When considered with the data published previously, this provides further evidence for rearrangements of plasmid DNA, perhaps associated with the presence of a transposon. The STaI probe hybridised to a 4.6-kb BamHI plasmid fragment from strain $\mathrm{B} 41^{*} \mathrm{Tc}^{\mathrm{s}} 1$ (an $\mathrm{STa}^{-}$derivative of strain $\mathrm{B} 41^{*}$ ) and the corresponding C600 transconjugant, thereby indicating the presence of at least a portion of the STaI gene, but did not hybridise with the other $\mathrm{STa}^{-}$ derivative, $\mathrm{B} 41^{*} \mathrm{Tc}^{\mathrm{s}} 2$, and its corresponding $\mathrm{C} 600$ transconjugant.

Previous studies have used DNA probes to identify the presence of the STaI gene in colony hybridisation experiments. Sommerfelt et al.$^{28}$ found that the digoxigenin system, as used in the present study, was suitable for colony hybridisation experiments with the addition of an extra blocking step with pre-hybridisation solution. This step was necessary to avoid a high background signal following hybridisation. In the present study, it was shown that this additional step could be omitted if hybridisation experiments were performed with Southern blots of crude plasmid DNA extracts. Higher probe concentrations could be used than those used by Sommerfelt et al. ${ }^{28}$ $(2 \cdot 4 \mathrm{ng} / \mathrm{ml})$, and the hybridisation mixture could be reused several times without loss of sensitivity.

Overall, the study demonstrated that, although it was not always easy to associate particular phenotypic characters with the presence of a particular plasmid, a non-radioactively labelled polynucleotide probe was an effective means of characterising the location of the STaI gene on plasmid DNA isolated from ETEC strains and their derivatives.
Part of this work was presented at a meeting of the Sociéte Française de Microbiologie held at the Institut Pasteur, Paris, France on 14 and 15 May 1990. I am grateful to Dr S. L. Moseley for providing strain G157 and to P. Menanteau for her participation in the characterisation of bacterial strains.

\section{References}

1. Gaastra W, De Graaf FK. Host-specific fimbrial adhesins of noninvasive enterotoxigenic Escherichia coli strains. Microbiol Rev 1982; 46: 129-161.

2. Klemm P. Fimbrial adhesins of Escherichia coli. Rev Infect Dis 1985; 7: 32I -340

3. De Graaf FK, Mooi FR. The fimbrial adhesins of Escherichia coli. Adv Microb Physiol 1986; 28: 65-143.

4. Schifferli DM, Beachey EH, Taylor RK. The 987P fimbrial gene cluster of enterotoxigenic Escherichia coli is plasmid encoded. Infect Immun 1990; 58: 149-156.

5. Thompson MR. Escherichia coli heat-stable enterotoxins and their receptors. Pathol Immunopathol Res 1987; 6: 103-116.

6. Gyles CL, So M, Falkow S. The enterotoxin plasmids of Escherichia coli. J Infect Dis 1974; 130 : 40-49.

7. Elwell LP, Shipley PL. Plasmid-mediated factors associated with virulence of bacteria to animals. Annu Rev Microbiol $1980 ; 34: 465-496$.

8. Smith HR, Scotland SM, Rowe B. Genetics of Escherichia coli virulence. In: Sussman M (ed) The virulence of Escherichia coli. London, Academic Press. 1985: 228-269.

9. Bertin A. Virulence factors of enterotoxigenic Escherichia coli studied in the infant mouse model. Ann Rech Vet 1983; 14: 169-182.

10. Duchet-Suchaux MF, Bertin AM, Menanteau PS. Susceptibility of Chinese Meishan and European Large White pigs to enterotoxigenic Escherichia coli strains bearing colonization factor K88, 987P, K99, or F41. Am J Vet Res 1991; 52 : 40-44.

11. Smith HW. The bacteriology of the alimentary tract of domestic animals suffering from Escherichia coli infection. Ann NY Acad Sci 1971 ; 176: 110-125.

12. Bertin A. F41 antigen as a virulence factor in the infant mouse model of Escherichia coli diarrhoea. J Gen Microbiol 1985 131 : 3037-3045.

13. Duchet-Suchaux M. Le souriceau, modèle d'étude de la diarrhée colibacillaire. Ann Microbiol (Inst Pasteur) 1980; 131B 239-250.

14. Duchet-Suchaux M, Le Maitre C, Bertin A. Differences in susceptibility of inbred and outbred infant mice to enterotoxigenic Escherichia coli of bovine, porcine and human origin. J Med Microbiol 1990; 31 : 185-190.

15. Duchet-Suchaux M. Protective antigens against enterotoxigenic Escherichia coli 0101: K99, F41 in the infant mouse diarrhoea model. Infect Immun 1988; 56: 1364-1370.

16. Fredericq P. Actions antibiotiques réciproques chez les enterobacteriaceae. Rev Belge Pathol Med Exp 1948; 19 Suppl IV: 1-107.

17. Dean AG, Ching YC, Williams RG, Harden LB. Test for Escherichia coli enterotoxin using infant mice: application in a study of diarrhea in children in Honolulu. $J$ Infect Dis 1972; 125: 407-411.

18. Kado CI, Liu S-T. Rapid procedure for detection and isolation of large and small plasmids. $J$ Bacteriol 1981; 145: 1365-1373.

19. Davis LG, Dibner MD, Battey JF. Basic methods in molecular biology. Amsterdam, Elsevier Science Publishing Co. 1986.

20. Birnboim HC, Doly J. A rapid alkaline extraction procedure for screening recombinant plasmid DNA. Nucleic Acids Res 1979; 7: 1513-1523.

21. Holmes DS, Quigley M. A rapid boiling method for the preparation of bacterial plasmids. Anal Biochem $1981 ; 114$ : 193-197.

22. Maniatis T, Fritsch EF, Sambrook J. Molecular cloning. A laboratory manual. New York, Cold Spring Harbor Laboratory. 1982.

23. Bialoskowa-Hobrzanska H. Detection of enterotoxigenic Escherichia coli by dot blot hybridization with biotinylated DNA probes. J Clin Microbiol 1987; 25: 338-341.

24. Casey TA, Moon HW. Genetic characterization and virulence 
of enterotoxigenic Escherichia coli mutants which have lost virulence gene in vivo. Infect Immun 1990; 58: 4156-4158.

25. So M, Heffron F, McCarty BJ. The $E$. coli gene encoding heat stable toxin is a bacterial transposon flanked by inverted repeats of IS1. Nature $1979 ; 277: 453-456$.

26. Meyers JA, Sanchez D, Elwell LP, Falkow S. Simple agarose gel electrophoretic method for the identification and characterization of plasmid deoxyribonucleic acid. $J$ Bacteriol 1976; 127: 1529-1537.
27. So M, Boyer HW, Betlach M, Falkow S. Molecular cloning of an Escherichia coli plasmid determinant that encodes for the production of heat-stable enterotoxin. J Bacteriol 1976; 128: $463-472$.

28. Sommerfelt H, Grewal HMS, Bhan MK. Simplified and accurate nonradioactive polynucleotide gene probe assay for identification of Escherichia coli.J Clin Microbiol 1990; 28: $49-54$. 